\title{
INSIDE OUTSIDE CIRCLE: TEACHING STUDENTS' SPEAKING SKILL
}

\author{
M. Sayid Wijaya \\ UIN Raden Intan Lampung \\ sayidwijaya@gmail.com \\ Melyta Sari \\ UIN Raden Intan Lampung \\ Mellyta_s@yahoo.co.id
}

\begin{abstract}
Speaking is an interactive process of constructing meaning that can involve producing and receiving and processing information. it is very important productive skill in our daily life as a connector for each other. The research was about the influence of using inside outside circle towards students' speaking skill at the eighth grade of SMP N 2 Sumberejo in the academic year of 2016/2017. The research is to know the influence of using inside outside circle toward speaking skill. The research methodology was quasi experimental design. In this research, the population was the seventh grade of SMP N 2 Sumberejo Tanggamus. The sample of this research was two classes consisting of 36 students for experimental class and 34 students for control class. In the experimental class, the researcher used Inside Outside Circle and in the control class the teacher used Dialogue Memorization Technique. The treatments were held in 3 meetings in which $2 \times 40$ minutes for each class. In collecting the data, the researcher used oral test instrument. Before giving the treatment, the researcher gave pre-test for both classes. Then, after conducting the treatments, the instrument was given in post-test. After giving pre-test and post-test, the researcher analyzed the data using SPSS to compute independent sample ttest. After giving the post test, the researcher analyzed the data by using independent sample t-test. It was found out that result of Sig. (Pvalue) $=0.012<\alpha=0.05$. It means that $\mathrm{Ho}$ is rejected and $\mathrm{Ha}$ is accepted. Therefore, there is a significant influence of using Inside Outside Circle towards students' speaking skill at the second semester of the eighth grade of SMP N 2 Sumberejo Tanggamus in the academic year of 2016/2017.
\end{abstract}

Keywords: speaking, dialogue, inside outside circle technique, quasi experimental

\section{BACKGROUND}

In language learning there are four skills. They are listening, speaking, reading and writing, speaking is one part of language skills that can be used for people to express their ideas orally in foreign language, when they are speaking, the students learn how to organize they ideas, express the language in spoken form. As stated by Cameron (2001) speaking is the active use of language to express meaning so that other people can make sense of them. Through speaking, they can express their ideas and communicate with other. According to Bown (2004) Speaking is an interactive process of constructing meaning that can involve producing and receiving and processing information. 
In order speaking is discussed in applied linguistics, speaking as interaction, speaking as a social and situation based activity. All these perspectives see speaking as an integral part of people's daily lives. Speaking is the oral part of communicative language assessment battery (Louma, 2004). So from those experts the researcher can conclude that speaking is one part of language skills that can be used for people to express their ideas orally in foreign language, when they are speaking, the students learn how to organize they ideas, express the language in spoken form.

In teaching learning process especially in speaking as a teacher usually finds some problems in teaching speaking activity. There are some problems faced by the teacher in teaching speaking activity in the classroom. The first is students will not talk or say anything, the second when students work in pairs or groups they just end up chatting in their own language, and the third when all the students speak together it gets too noisy and out of hand and lose control of the classroom (Maley, 2001). Those problems are also found at SMP Negeri 2 Sumberejo.

In teaching speaking skill, there are many activities that can be used to teach speaking, one of them is inside outside circle. Acording to Kagan in ( Lie, 2008 ) inside outside circle is a technique in the class, students stand in two straight lines facing each other. One lines rotate, and the other remains in place. Rotating students rotate to a new partner and rotate to the back of their line when they pass the last student in the fixed line

\section{Speaking}

Many experts have differently defined the word Speaking. According to Louma (2004) Speaking is discussed in applied linguistic, speaking as interaction, speaking as a social and situation based activity, these perspectives speaking as an integral part of people's daily lives. Thornbury (2001) states that speaking is so much a part of daily life that we take.

However, according to McKay (2006) states that when people speak, it is not the case that the simply open their mouths and speak the words and sentences, when people speak, they are doing so in a cultural context, they are speaking to another person or persons (perhaps friend, a teacher or a tester) who bring with them a relative degree of status and power and they are doing so in order to meet the purpose required of the interaction, which may be a conversation, or a task that needs complementing. Brown (2004 ) speaking is a productive skill that can be directly and empirically observed It means that in the process of speaking there must be at least two persons: the first person is a speaker who gives information and the second person is a listener who receives information. They are part of speakers. Every speaker should express what they want to say and directly answer the question that given.

\section{Speaking Skill}

Louma (2004) Speaking skill is an important part of the curriculum in language teaching, and this makes them an important object of assessment as well. Furthermore Harmer (2001) states that the ability to speak English supposes the elements necessary for spoken productions as follows: 


\section{Language features}

The elements necessary for spoken productions, are the following:

a. Connected speech: in connected speech sounds are modified (assimilations), omitted (elision), added (linking r), or weakened (through contractions and stress pattering). It is for this reason that we should involve students in activities designed specifically to improve their connected speech

b. Expressive device: native speakers of English change the pitch and stress of particular parts of utterances, vary volume and speed, and show by order physical and non-verbal (paralinguistic) means how they are feeling (especially in face- to- face interaction). The use of these devices contributes to the ability to convey meanings.

c. Lexis and grammar: teachers should therefore supply a variety of phrase for different functions such as agreeing or disagreeing, expressing surprise, shock, or approval.

d. Negotiation language: effective speaking benefits from the negotiator language we use to seek clarification and show the structure of what we are saying. We often need to ask for clarification when we are listening to someone else talks and it is very crucial.

\section{Mental or social processing}

Success of speaker's productivity is also dependent upon the rapid processing skills that talking necessitates

a. Language processing: language processing involves the retrieval of words and their assembly into syntactically and propositionally appropriate sequence

b. Interacting with others: effective speaking also involves a good deal of listening, an understanding of how the other participants are feeling, and knowledge of how linguistically to take turns or allow others to do so

c. (On the spot) information processing: quite apart from our response to other's feelings, we also need to be able to process the information they tell us the moment we get it.

It can be concluded that speaking has two element (Language features and Mental or social processing), language features involve four areas : connected speech, expressive decide, lexis and grammar, and negotiation language. Supposing the speaker processes these languagefeatures, processing skills, mental/social processing, will help them to achieve sucessfull communication.

\section{Dialogue}

Dialogue is a meaningful interaction and exchange between individuals and/or people of different groups (social, cultural, political and religious) who come together through various kinds of conversations or activities with a view to increased understanding Auntumn (2004). It means dialogue is exchange comunication or conversations should be happen include two persons or more to increased understanding.

Acording to Basiwi (2006) Dialogue is written conversation between two or more people on regular basic. Dialogue is oral production come in the form of conversation 
(Bown, 2000)Therefore dialogue is short conversations including to show learners how spoken English sound of new vocabulary to be learn.

It can be concluded that dialogue is a meaningful interaction by two people or can be used to learning in the class or talk an exchange opinion in speaking skill and in dialogue students involve directly in using the language. They can interact one another, transferring their information or ideas by speaking. In dialogue students are invited to take a part in interaction with others. Here the researcher used dialogue to teaching speaking by using inside outside circle (IOC).

\section{Inside Outside Circle}

Inside outside circle is group learning activity organized in such away that learning is based on the socially structured change of information between learners in group in which each learner is held accountable for his or her own learning and is motivated to increase the learning of others (Huda, 2011). Acording to Kagan (2009) Inside outside circle is group learning in the class, students stand in two straight lines facing each other. One lines rotate, and the other remains in place. Rotating students rotate to a new partner and rotate to the back of their line when they pass the last student in the fixed line. It can be concluded that inside outside circle is group learning activity organized in such away that learning is based on the socially structured change of information between learners in group, which in the group is rotating students rotate to a new partner.

Furthemore, Kagan state in Liang (2002) Inside Outside Circle is group work of four or six students stood in pair in two concentric circles, with the inside circle facing out and the outside circle facing in, students could use card or respond to teacher questions as they rotate to each new partners. It could be a good technique for checking understanding, reviewing, processing, practicing dialogues in textbooks, and meeting classmates. It gives students an opportunity to talk with different partners and exchange academic language( Beltran, 2013).

It means inside outside circle is the technique learning in the class as they rotate to each new partner or different partner to be checking understanding, reviewing, processing, and practicing the students this strategy will give students an ooporunity to change knowledge with different partner. English teacher must have strategy to teach speaking effectively in the classroom. It is used to make the students know their knowledge and capability in speaking. The students can be applying their speaking ability in daily communication. Stanne states inside outside circle is a summarization technique that get students up and moving. As stated by Mitarsono (2012) It holds all students accountable for having something to say/share.

\section{a. The Procedure of Teaching Speaking Through Inside Outside Circle Technique}

1. The teacher prepares questions, or provides a question card for each students.

2. Students form pairs. One students from each pair moves to form one large circle in the class facing outward.

3. Remaining students find and face their partner (class now stands in two concentric circles). 
4. Inside students ask a question from their question cards; outside circle answer. Inside circle students praise or coach (alternative: the teacher asks a question and indicates inside or outside to answer to their partner)

5. Partners switch roles: outside circle students ask, and them praise coach.

6. Partners trade question card.

7. The teacher gives the limit time for speaking.

8. Inside circle students rotate clockwise to a new partner. Do it until finish (Kagan, 2009).

\section{Dialogue Memorization}

Dialogue memorizationtechnique is a kind of technique that encourage students to speak by providing them short conversation between two people. To complete the activity, they should memorize the dialogue through mimicry and they also memorize their partner's lines( Larsen, 2000 ) It means dialogue memorizing technique is kind of technique that is appropriate to be used in speaking activity which used short dialogue to be memorized.

\section{METHOD}

There are two variables that are analyzed in this research. They are independent variable and dependent variable. The independent variable in this research is inside outside circle $(\mathrm{X})$, and the dependent variable in this research are students' speaking skill (Y). Therefore, to analyze those variables this research uses quantitative research, : In conducting research, the researcher used quantitative research based on the experimental research, the researcher used experimental design. Experimental design is the general plan to carrying out a study with and active independent variable. The design is important because it determines then study's internal validity, which is the ability to reach valid conclusion about the effect of the experimental treatment on the dependent variable (Ary, 2010). Through this research information about students' speaking skill is expected to be obtained.

In this research the researcher used quasi experimental pre-test post-test group. The variety of quasi-experimental designs which can be devided into two main categories, one of them is pretest-postest control group design (Ary, 2010)

\section{FINDINGS}

After calculating the data from achievement of Pre-test and Post-test, the result shows the mean of post-test higher than pre-test.

\section{Data Analysis}

After collecting the data, the researcher analyzed the data by using independent $t-$ test. There were two assumptions that must be done before the researcher analyzed the data by using independent sample t-test.

\section{1) Fulfillment of the Assumptions}

Before knowing the result of the data analysis by using independent sample t-test, there were two assumptions that must be done and found out. They were normality test and homogeneity test. 


\section{a. The Result of Normality Test}

The normality test is used to measure weather the data in the experimental class and control classes are normally distributed or not. In this research the researcher used statistical computations by using SPSS (Statistical Package for Social Science) for normality. The tests of normality employed are Kolmogorov - Smirnov and Shapiro Wilk.

The hypothesis formulas of the test were:

$\mathrm{H}_{\mathrm{o}}=$ the data have normal distribution.

$\mathrm{H}_{\mathrm{a}}=$ the data do not have normal distribution.

The criteria of acceptance or rejection of the hypothesis for normality test were:

$\mathrm{H}_{\mathrm{o}}$ is accepted if Sig. $\left(\mathrm{P}_{\text {value }}\right) \geq \alpha=0.05$

$\mathrm{H}_{\mathrm{a}}$ is accepted if Sig. $\left(\mathrm{P}_{\text {value }}\right)<\alpha=0.05$

Table 1

The Result Normality of the Experimental and Control Class

\begin{tabular}{crrrrrr}
\hline \multirow{2}{*}{ Technique } & \multicolumn{3}{c}{ Kolmogorov-Sminorv $^{\mathrm{a}}$} & \multicolumn{3}{c}{ Shapiro-Wilk } \\
\cline { 2 - 8 } & Statistic & \multicolumn{1}{c}{$\mathrm{df}$} & \multicolumn{1}{c}{ Sig. } & Statistic & df & \multicolumn{1}{c}{ Sig. } \\
\hline Ex & .204 & 35 & $.301^{*}$ & .863 & 35 & .358 \\
Co & .113 & 35 & $.200^{*}$ & .971 & 35 & .468 \\
\hline
\end{tabular}

a. Lilliefors Significance Correction

*. This is a lower bound of the true significance

Note: Technique $1=$ Experimental class

Technique 2 = Control Class

Based on Table VII, it could be seen that $\mathrm{P}_{\text {value }}(\mathrm{Sig}$.) for experimental class was 0.301 for Kolmogorov-Sminorv ${ }^{\mathrm{a}}$ and 0.468 for Shapiro-Wilk. Because Sig. $\left(\mathrm{P}_{\text {value }}\right)$ of experimental class $>\alpha 0.05$ it means $\mathrm{H}_{\mathrm{o}}$ is accepted and Sig. $\left(\mathrm{P}_{\text {value }}\right)$ for the control class $>\alpha 0.05$ it means $\mathrm{H}_{\mathrm{a}}$ is accepted. The conclusion was that the data in the experimental class and for the control class had normal distribution

\section{Result of Homogeneity Test}

Homogeneity test is used to determine whether the data obtained from the sample homogenous or not. The researcher used statistical computation by using SPSS (Statistical Package for Social Science) for homogeneity. The test of homogeneity employing Levine's test.

The hypothesis for the homogeneity tests are:

$\mathrm{H}_{\mathrm{O}}=$ the variances of the data are homogenous

$\mathrm{H}_{\mathrm{a}}=$ the variances of the data are not homogenous

The criteria of acceptance or rejection of the hypothesis for homogeneity test were:

$\mathrm{H}_{\mathrm{o}}$ is accepted if Sig. $\geq \alpha=0.05$ 
$\mathrm{H}_{\mathrm{a}}$ is accepted if Sig. $>\alpha=0.05$

Table 2

The Result Homogeneity Test

\begin{tabular}{lcccc}
\hline & $\begin{array}{c}\text { Levene } \\
\text { Statistic }\end{array}$ & df1 & df2 & Sig. \\
\hline Score Based on Mean & .080 & 1 & 68 & .778 \\
\hline
\end{tabular}

Based on the results obtained in the test of homogeneity of variances in the column, it could be seen that Sig. $\left(\mathrm{P}_{\text {value }}\right)=0.778>\alpha=0.05$. it demonstrated that $\mathrm{H}_{\mathrm{o}}$ was accepted because Sig. $\left(\mathrm{P}_{\text {value }}\right)>\alpha=0.05$. it means that the variance of the data was homogenous.

\section{Result of Hypothetical Test}

Based on the previous explanation that the normality and homogeneity test were satisfied, therefore, the researcher tested the hypothetical test using parametrical statistic, independent sample t-test.

The hypotheses formulas are:

$\mathrm{H}_{\mathrm{a}}$ : There is significant influence of using Inside Outside Circle towards students' Speaking Skill at the second semester of the Eighth grade of SMP N 2 SumberejoTanggamus in the academic year of 2016/2017.

$\mathrm{H}_{0} \quad$ : There is no significant of using Inside Outside Circle towards students' Speaking skill at the second semester of the Eighth grade of SMP N 2 SumberejoTanggamus in the academic year of 2016/2017.

The criteria of acceptance or rejection of the hypothesis for Hypothetical test was:

$\mathrm{H}_{\mathrm{a}}$ is accepted if Sig. $<\alpha 0.05$

$\mathrm{H}_{\mathrm{o}}$ is accepted if Sig. $\leq \alpha 0.05$

Table 3

The Result of Hypothetical Test

\begin{tabular}{ccc}
\hline $\mathrm{T}$ & $\mathrm{Df}$ & Sig. (2-tailed) \\
\hline 1.799 & 68 & .012 \\
\hline
\end{tabular}

Based on the result obtained in the independent sample t-test in the table 1 that the value of significant generated Sig. $\left(\mathrm{P}_{\text {value }}\right)=0.012<\alpha=0.05$. So, $\mathrm{H}_{\mathrm{o}}$ is rejected and $\mathrm{H}_{\mathrm{a}}$ is accepted. Based on the computation, it could be concluded that there was a significant influence of using Inside Outside Circle towards students' Speaking Skill at the second semester of the Eighth grade of SMP N 2 Sumberejo Tanggamus in the academic year of 2016/2017. 


\section{DISCUSSION}

At the beginning of the research, the pre-test was administered to know students' achievement in speaking skill before they were given treatments by the researcher. The result showed that the mean score of pre-test between experimental class was 55.44 and the mean score pre-test in control class was 54.88.

Afterward the students were taught by using Inside Outside Circle in the experimental class and dialogue memorization in control class. The material was three topic of dialogue invitation for three treatments. Before doing Inside Outside Circle the researcher explained what Inside Outside Circle and how we do the procedure of Inside Outside Circle in the beginning of treatment the researcher asked the students about invitation and explained it also given example to the students.

At the end of the research, post-test was given to measure the improvement of the students speaking skill in both classes after the treatments done. The mean score of post-test in experimental class was 76.25 and mean of post test in the control class was 69.56. It means teaching speaking by inside outside circle more effective and by using inside outside circle can increase their speaking score.

From the result, we can see that result of the students' pos-test is higher than pre-test. Besides that Inside Outside Circle can improve each aspect of students speaking skill including pronunciation, grammar, vocabulary, fluency, comprehension. The result of pre-test and post-test also showed that students who taught by using Inside Outside Circle got better result that students who taught by using Dialogue Memorization.

Based on the analysis of the data and the testing of hypothesis, the result of $\mathrm{T}$ test null hypothesis $\left(\mathrm{H}_{0}\right)$ is refused and alternative hypothesis $\left(\mathrm{H}_{\mathrm{a}}\right)$ is accepted. It means that treatment had influence of using Inside Outside Circle towards students speaking skill at the second semester of the Eighth grade of SMP N 2 Sumberejo, Tanggamus so alternative hypothesis is accepted. It had been supported by the previous research that was done by Astuti entitled " The Influence of Using Inside Outside Circle Towards students' Reading Comprehension In Narrative Text". She said that Inside Outside Circle is very effective to be implemented in teaching and learning.

\section{CONCLUSION}

After conducting the research and analyzing the data the researcher draws a conclusion as follows: There is a significant influence of using Inside Outside Circle towards students' speaking skill. Because by seeing the result of the data calculation in the previous chapter where null hypothesis $\left(H_{o}\right)$ was rejected, and alternative hypothesis $\left(H_{a}\right)$ was accepted, it means that the researcher's assumption is true, that is, Inside Outside Circle technique can give a significant influence towards students' speaking Skill. It was supported by the scores achieved by the students in which they got higher scores after the researcher gave the treatment Inside Outside Circle as a technique for teaching speaking. The significant can be seen from Sig ( 2-tailed) of the equal variance assumed in the independent sample t-test table where the Sig (2-tailed) is 0.000. it is lower than $\alpha=0.05$ and its mean $H_{o}$ its rejected and $H_{a}$ is accepted. It can be revealed from the hypothetical test, where alternative hypothesis is accepted and null hypothesis is rejecte 


\section{REFERENCES}

Auntumn.2004. Journal of Dialogue Studies : Institut for Dialogue Studies. London.

Basiswi, Gundah.2006. Journal of Effeectivenes Students' Writing Skill in Narrative, State Univesity : Malang.

Beltran,Doloreset.al, Science for English Language Learners, (Shell Education, 2013).

Brown, H. Douglas.2000. Teaching by Principle An Interactive Approach to Language Pedagogy, Second Edition : Longman.

Brown, H. Douglas.2001. Teaching by Principle An Interative Approach to Language Pedagogy, 2nd Ed. San Fransisco : Longman.

Brown, H. Douglas.2003.Language Assessment Principle and Classroom Practices. San Francisco : California

Brown, H. Douglas.2004. Language Assesment : Principles and Classroom Practices, New York : Pearson Education.

Cameron, Linne. 2001. Teaching Language to Young Learners, London: Cambridge University.

Creswell John W.2008.Educational Research, $4^{\text {th }}$ Edition, Boston: Pearson Education.

Cheser Jacob, DonalAryand Chris Sorensen,2010. Introduction to Research in Education ( $8^{\text {th }}$ edition), Canada: WardsworthCengae Learning.

Gay L. R. 1987. Educational Research: Competencies for Analysis and Application, $3^{\text {rd }}$ Edition, Colombus Ohio: Merril Publishing Company.

Hamad, Fahad Aljumlah.2011. Developing Studi EFL Students'Oral Skill: An Introgative Approach, Qosim University : Buraidah.

Harmer, Jeremy. 2007, How to Teach English, Longman : England.The Practice of English Language Teaching, (Thrid Edition Completely Revisedand Update).

Huda, Miftahul, 2011.Cooperative Learning, (Metode, Tehnik, Structure, dan Model Penerapan )1st Edition.

Fraenkel Jack R. and Norman E. Wallen1993. How to Design and Evaluate Research and Education, Singapore: McGraw- Hill Book Co.

Lie, Anita. 2008. Cooperative Learning : Mempraktikkan cooperative Learning di Ruang-Ruang Kelas. Jakarta : Grasindo.

Luoma, Sari. 2004. Assesing Speaking, New York, Cambridge : University Press.

McKay Penny.2006.Assessing Young Language Learners, Cambridge:Cambridge University Press.

Pajupu Hille, 2010.et . Al, Natural Speaking and How to Asses It, Insitute of the Estonian Language, New York,

Mintarsono Gatot, The Effectiveness of Inside-Outside Circle to Teach Reading.2012.

Robert Paul, Understanding Grammar, ( San Jose State College : Newyork) 1994.

Samuel Carolyn, 2010. In The ClasroomPronounciation Pegs, TESL Canada

Journal/Revue TESL Du Canadavol. 27, No 2, Spring.

Thornbury Scott. 2001.How to Teach Speaking, English : Longman.

Tsailing, 2002. Liang, Implementing Cooperative Learning in EFL Teaching :

Process and effects.

Turk, Christopher.2003.Effective Speaking Communicating In Speech, Francis: Spoon Press. 
Patel, Parina, 2013. Introduction to Quantitative Methods,(Empirical Law Seminar: 2009 ) SP, KaurVariable in Research, (Review article).

\section{Internet Sources}

Kagan Spencer and Miguel, Kagan, Kagan Cooperative Learning, (Kagan Publising)

Kagan Spencer, Thoughta on Cooperative learning, Availble on http://www.teachnology.com/currends/cooperative_learning/kagan/

Maley Alan, Classroom Problems in Teacher British council, available on: http://www.teachingenglish.orng.uk/article/teaching-speakingskills2overcoming-classroom-problem, [ September 19 $\left.{ }^{\text {th }}, 2016\right]$. 